\title{
Erratum to clinical effect and safety of venous access ports and peripherally inserted central catheters in patients receiving tumor chemotherapy: a systematic review and meta-analysis
}

\author{
Editorial Office \\ Annals of Palliative Medicine \\ Correspondence to: Editorial Office. Annals of Palliative Medicine. Email: apm@amepc.org.
}

Submitted Nov 01, 2021. Accepted for publication Nov 19, 2021.

doi: 10.21037/apm-2021-08

View this article at: https://dx.doi.org/10.21037/apm-2021-08

Erratum to: Ann Palliat Med 2021;10:9105-13

This article (1) that appeared on Page: 9105-9113, Vol 10, No 8 (August 2021) Issue of the Annals of Palliative Medicine (APM) was published with mistakes in the department and contribution statement of the authors. Specifically, Dr. Erling He is from the Hemodialysis Room and Dr. Kunni Ye is from the Department of Urology, rather than Department of Rehabilitation Medicine. Besides, as Dr. Erling He and Dr. Kunni Ye contributed equally to the article, a statement "These authors contributed equally to this work" needed to be added at the end of the contribution statement. The corrected version of author affiliation and contributions is presented below:

Erling $\mathrm{He}^{1 \#}$, Kunni Ye ${ }^{2 \#}$, Huili Zheng ${ }^{3}$

${ }^{1}$ Hemodialysis Room, Hainan Western Central Hospital, Danzhou, China; ${ }^{2}$ Department of Urology, Hainan Western Central Hospital, Danzhou, China; ${ }^{3}$ Department of Rehabilitation Medicine, Hainan Western Central Hospital, Danzhou, China

Contributions: (I) Conception and design: H Zheng; (II) Administrative support: H Zheng; (III) Provision of study materials or patients: K Ye; (IV) Collection and assembly of data: E He, K Ye; (V) Data analysis and interpretation: E He, K Ye; (VI) Manuscript writing: All authors; (VII) Final approval of manuscript: All authors.

\#These authors contributed equally to this work.

Correspondence to: Huili Zheng. Department of Rehabilitation Medicine, Hainan Western Centra Hospital, Danzhou 571799, China. Email: 420598596@qq.com.

Click here to view the updated version of the article.

Open Access Statement: This is an Open Access article distributed in accordance with the Creative Commons AttributionNonCommercial-NoDerivs 4.0 International License (CC BY-NC-ND 4.0), which permits the non-commercial replication and distribution of the article with the strict proviso that no changes or edits are made and the original work is properly cited (including links to both the formal publication through the relevant DOI and the license). See: https://creativecommons.org/licenses/by-nc$\mathrm{nd} / 4.0 /$. 


\section{References}

1. He E, Ye K, Zheng H. Clinical effect and safety of venous access ports and peripherally inserted central catheters in patients receiving tumor chemotherapy: a systematic review and meta-analysis. Ann Palliat Med 2021;10:9105-13.

Cite this article as: Editorial Office. Erratum to clinical effect and safety of venous access ports and peripherally inserted central catheters in patients receiving tumor chemotherapy: a systematic review and meta-analysis. Ann Palliat Med 2021;10(12):13035-13036. doi: 10.21037/apm-2021-08 